\title{
Promoter methylation of tumor-related genes as a potential biomarker using blood samples for gastric cancer detection
}

\author{
Jinfeng Wen ${ }^{1}$, Tuo Zheng ${ }^{2}$, Kefeng Hu${ }^{1}$, Chunxia Zhu ${ }^{1}$, Lihua Guo ${ }^{1}$ and Guoliang Ye ${ }^{1}$ \\ ${ }^{1}$ Department of Gastroenterology, The Affiliated Hospital, School of Medicine, Ningbo University, Ningbo, Zhejiang 315020, \\ People's Republic of China \\ ${ }^{2}$ Department of Gastroenterology, Ningbo No.1 Hospital, Ningbo, Zhejiang 315000, People's Republic of China \\ Correspondence to: Guoliang Ye, email: ndfyygl@163.com \\ Keywords: tumor-related gene, promoter methylation, blood, GC, diagnosis \\ Received: July 02, $2017 \quad$ Accepted: July 30, $2017 \quad$ Published: September 08, 2017 \\ Copyright: Wen et al. This is an open-access article distributed under the terms of the Creative Commons Attribution License 3.0 \\ (CC BY 3.0), which permits unrestricted use, distribution, and reproduction in any medium, provided the original author and source \\ are credited.
}

\section{ABSTRACT}

Gene promoter methylation has been reported in gastric cancer (GC). However, the potential applications of blood-based gene promoter methylation as a noninvasive biomarker for GC detection remain to be evaluated. Hence, we performed this analysis to determine whether promoter methylation of 11 tumor-related genes could become a promising biomarker in blood samples in GC. We found that the cyclindependent kinase inhibitor $2 \mathrm{~A}(\mathrm{p16})$, E-cadherin (CDH1), runt-related transcription factor 3 (RUNX3), human mutL homolog 1 (MLH1), RAS association domain family protein 1A (RASSF1A), cyclin-dependent kinase inhibitor 2B (p15), adenomatous polyposis coli (APC), Glutathione S-transferase P1 (GSTP1), TP53 dependent G2 arrest mediator candidate (Reprimo), and 06-methylguanine-DNAmethyl-transferase (MGMT) promoter methylation was notably higher in blood samples of patients with GC compared with non-tumor controls. While death-associated protein kinase (DAPK) promoter methylation was not correlated with GC. Further analyses demonstrated that RUNX3, RASSF1A and Reprimo promoter methylation had a good diagnostic capacity in blood samples of GC versus non-tumor controls (RUNX3: sensitivity $=63.2 \%$ and specificity $=97.5 \%$, RASSF1A: sensitivity $=61.5 \%$ and specificity $=96.3 \%$, Reprimo: sensitivity $=\mathbf{8 2 . 0} \%$ and specificity $=\mathbf{8 9 . 0} \%$ ). Our findings indicate that promoter methylation of the RUNX3, RASSF1A and Reprimo genes could be powerful and potential noninvasive biomarkers for the detection and diagnosis of GC in blood samples in clinical practices, especially Reprimo gene. Further well-designed (multicenter) and prospective clinical studies with large populations are needed to confirm these findings in the future.

\section{INTRODUCTION}

Gastric cancer (GC) is the fifth most common malignant tumor and the third leading cause of death in all human cancers worldwide [1]. Based on GLOBOCAN estimates, approximately 951,600 new cases were clinically diagnosed with GC, leading to about 723,100 deaths in 2012 worldwide [1]. Approximately $70 \%$ of GC cases occur in developing countries [2]. Although early detection and treatment have improved survival in early gastric cancer patients, numerous patients with GC are usually diagnosed at advanced stage, with a high mortality rate $[3,4]$. Therefore, novel noninvasive and low-cost biomarkers are of importance for early diagnosis and screening of GC.

As a common epigenetic alteration, DNA methylation is associated with human cancers [5-7]. Aberrant DNA methylation of tumor-related genes could be a noninvasive biomarker using body fluid samples (blood or urine etc.) for detecting cancer [8-11]. The cell- 
cycle inhibitory proteins, tumor suppressor genes (TSGs) p16: cyclin-dependent kinase inhibitor $2 \mathrm{~A}(C D K N 2 A)$ and p15: cyclin-dependent kinase inhibitor $2 \mathrm{~B}(C D K N 2 B)$ are linked to the p53 and retinoblastoma $(\mathrm{Rb})$ pathways [12]. TSG CDH1 is termed as epithelial cadherin (E-cadherin) or cadherin-1 and is associated with the invasion and metastasis of cancer $[13,14]$. Runt-related transcription factor $3(R U N X 3)$ was reported as a new gastric TSG in 2002 and the loss of $R U N X 3$ expression is related to gastric carcinogenesis [15]. Human mutL homolog 1 (MLH1) encoding a DNA mismatch repair (MMR) protein and lack of $M L H 1$ expression is associated with genomic instability in gastric cancer $[16,17]$. RAS association domain family protein $1 \mathrm{~A}(R A S S F 1 A)$ as a TSG has some biological roles in the regulation of cell cycle, microtubule stability, and apoptosis [18]. The adenomatous polyposis coli $(A P C)$ gene is a TSG involved in multiple functions, including WNT signaling, cell cycle regulation, cell differentiation and proliferation, and transcriptional activation etc. [19]. Glutathione S-transferase P1 (GSTP1) is identified as a TSG and has an important function in preventing normal cells against damage by various carcinogens or electrophilic compounds [20, 21]. TP53 dependent G2 arrest mediator candidate (Reprimo) is involved in cell cycle regulation [22]. Death-associated protein kinase $(D A P K)$, a calcium/calmodulin-dependent serine/threonine kinase, is related to these functions of apoptosis, autophagy, and inflammation [23]. O6methylguanine-DNAmethyl-transferase (MGMT), a DNA repair gene, protects cells against the effects of treatment via eliminating alkyl adducts from the O6-position of guanine [24, 25]. Multiple tumor-related genes are found to be commonly methylated in tissue samples in GC, such as p16, CDH1, RUNX3, MLH1, RASSF1A, p15, APC, $D A P K$, GSTP1, Reprimo, and MGMT etc. [22, 26-28].

However, the potential value of the diagnosis of gene promoter methylation in the blood as a promising noninvasive biomarker in GC patients remains to be determined. The purpose of this study was to perform a systematic analysis of all possible candidate genes rather than an individual gene associated with blood-based gene methylation in diagnosing GC.

\section{RESULTS}

\section{Study characteristics}

According to the described search method, as shown in Figure 1, there were 50 publications published from 2002 to 2017 in the present study. Data involving 51 methylated genes were determined in blood samples of patients with GC from China, Japan, Korea, Iran, Thailand, Chile, Greece, Russia, and Singapore. Supplementary Table 1 lists the detailed characteristics

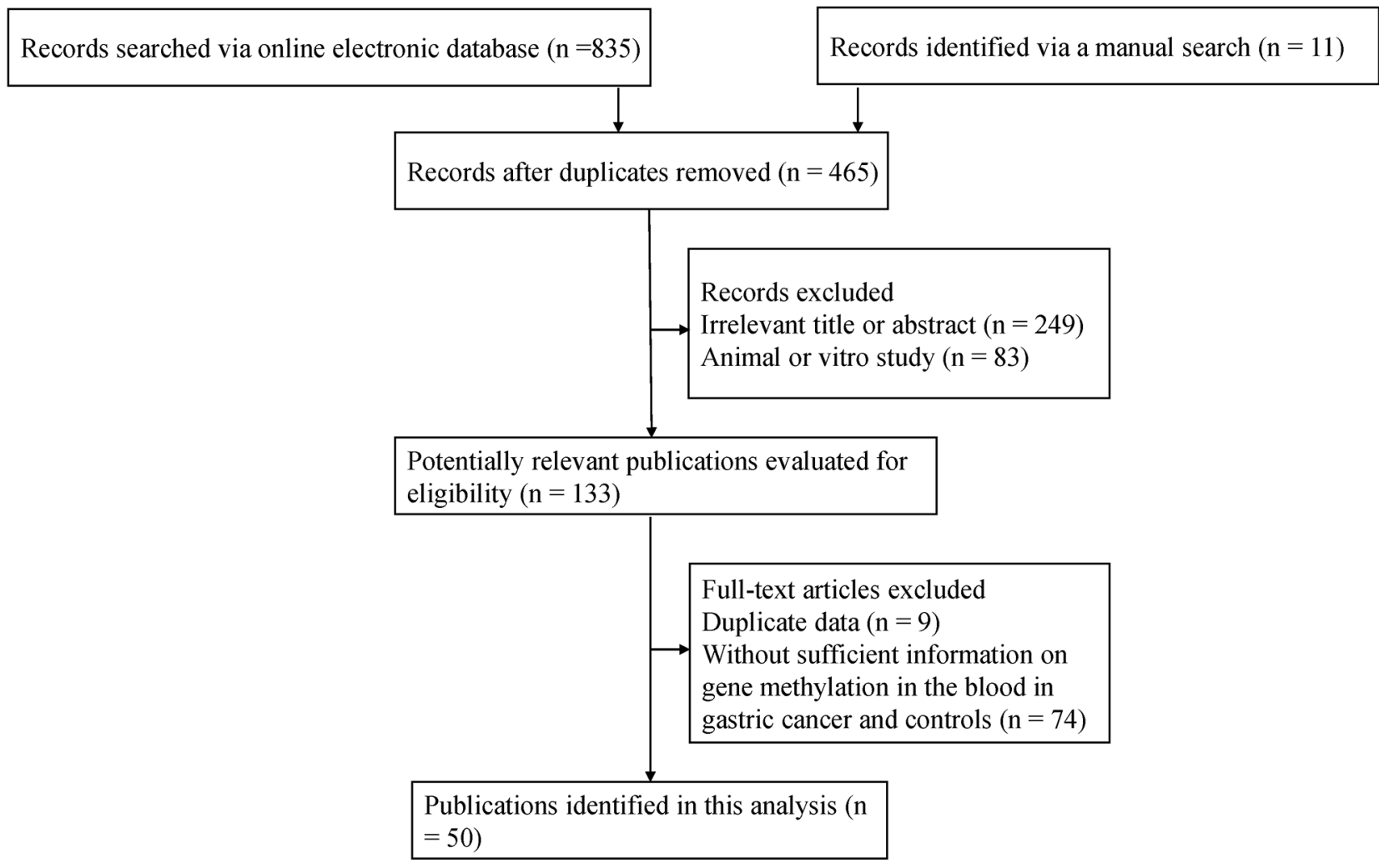

Figure 1: Flow diagram of the search method of the eligible studies in this systematic analysis. 
of the eligible studies on blood samples of GC and non-tumor controls. This systematic analysis mainly investigated these methylated genes with more than two studies.

\section{Gene promoter methylation in the blood in GC}

The analyses of more than two studies included 11 tumor-related genes within promoter methylation in blood samples of GC. When GC was compared to non-tumor controls, the results showed that promoter methylation ofthe $p 16(\mathrm{OR}=14.21,95 \% \mathrm{CI}=4.18-48.23, P<$ $0.001), C D H 1(\mathrm{OR}=18.19,95 \% \mathrm{CI}=7.38-44.80, P<$ $0.001), R U N X 3(\mathrm{OR}=63.66,95 \% \mathrm{CI}=13.42-302.02, P$ $<0.001), M L H 1(\mathrm{OR}=6.81,95 \% \mathrm{CI}=2.84-16.35, P<$ $0.001), R A S S F 1 A(\mathrm{OR}=64.15,95 \% \mathrm{CI}=32.29-127.47$, $P<0.001), p 15(\mathrm{OR}=7.92,95 \% \mathrm{CI}=2.41-26.09, P=$ $0.001), A P C(\mathrm{OR}=15.60,95 \% \mathrm{CI}=1.24-196.14, P=$ $0.033)$, GSTP1 $(\mathrm{OR}=5.75,95 \% \mathrm{CI}=1.05-31.62, P=$ $0.044)$, Reprimo $(\mathrm{OR}=111.10,95 \% \mathrm{CI}=36.67-336.59$, $P<0.001)$, and $M G M T(\mathrm{OR}=3.16,95 \% \mathrm{CI}=1.47-6.81$, $P=0.003$ ) was significantly correlated with $\mathrm{GC}$ in blood samples (Figures 2-5). No significant correlation was found between $D A P K$ promoter methylation and GC (OR $=7.82,95 \% \mathrm{CI}=0.92-66.26)($ Figure 5$)$.

Supplementary Table 2 presents the remaining 40 genes investigated among less than three studies. Of these genes, 20 methylated genes were shown to be significantly associated with GC in the blood (Supplementary Table 2), additional studies with large populations should be done to confirm the results of gene methylation with fewer than three studies.

\section{Subgroup analysis of $p 16$ promoter methylation}

According to the eligible subgroups, a subgroup analysis of testing method ((methylation specific PCR (MSP) and non-methylation specific PCR (NonMSP)) was conducted in p16 promoter methylation (Supplementary Figure 1). The result demonstrated that p16 promoter methylation was correlated with $\mathrm{GC}$ in the MSP method $(\mathrm{OR}=20.88,95 \% \mathrm{CI}=8.28-52.64, P<$ $0.001)$, but not in the Non-MSP method (OR $=7.46,95 \%$ $\mathrm{CI}=0.15-360.60, P=0.310$ ).

\section{Sensitivity analyses}

For the results with substantial heterogeneity among more than two studies ( $p 16, R U N X 3$, and $A P C$ genes: $P<$ 0.1 , we conducted sensitivity analyses to determine the stability of the overall OR and the change of heterogeneity based on the omission of a single study.

When one study (Leung 2005 et al) [29] was removed in 16 promoter methylation, the pooled OR of p16 promoter methylation was $25.31(95 \% \mathrm{CI}=11.29$ $56.76, P<0.001)$, while heterogeneity was significantly reduced $(P=0.880)$.
The OR value of $R U N X 3$ promoter methylation was $27.28(95 \% \mathrm{CI}=11.89-62.62, P<0.001)$ by removing a single study by Lu 2012 et al [30], which caused the absence of heterogeneity $(P=0.783)$.

When we removed this study by Bernal 2008 et al [22], and re-calculated the combined $\mathrm{OR}$ value of $A P C$ promoter methylation $(\mathrm{OR}=40.98,95 \% \mathrm{CI}=7.25$ $231.79, P<0.001)$, resulting in a dramatically decreased heterogeneity $(P=0.333)$.

\section{Publication bias}

Egger's test was used to measure the potential publication bias for the results with greater than five studies ( $116, C D H 1, R U N X 3$, and $M L H 1$ genes). Figure 6 shows the statistical data of funnel plot symmetry, which indicted the absence of publication bias regarding promoter methylation of the CDH1, RUNX3, and $M L H 1$ genes $(P>0.05)$. There was a slight publication bias for $p 16$ promoter methylation $(P=0.039<0.05)$.

\section{Gene promoter methylation in relation to clinicopathological features of GC}

We analyzed other clinical effects of $p 16$, RASSF 1A, DAPK, and $p 15$ promoter methylation with the clinicopathological characteristics of patients with GC in the blood. p16 promoter methylation was not correlated with gender, age and lymph node status $(P>0.1)$ (Supplementary Figure 2), while a positive relationship was found between p16 promoter methylation and clinical stage $(\mathrm{OR}=2.21,95 \% \mathrm{CI}=1.10-4.42, P=0.025)$ (Supplementary Figure 2).

No correlation was found between RASSF1A, DAPK, and $p 15$ promoter methylation and clinicopathological features of GC (Supplementary Figure 3) (all $P S>$ 0.1 ), including gender and age for RASSF1A promoter methylation; gender and lymph node status for $p 15$ promoter methylation; and gender, clinical stage or lymph node status for $D A P K$ promoter methylation. Because the sample sizes of the correlation of gene promoter methylation with clinicopathological characteristics were small in blood samples of GC patients. These results should be cautious.

\section{DISCUSSION}

Increasing evidence demonstrated the use of promoter methylation of some tumor-related genes as a powerful noninvasive biomarker for the detection and diagnosis of cancer in the blood in clinical settings [3133]. However, the diagnostic role of promoter methylation status of the tumor-related genes in blood samples of patients with GC lacks quantitative assessment. Therefore, an integrated analysis was performed to evaluate the ability of 11 tumor-related genes ( $p 16, C D H 1, R U N X 3$, 


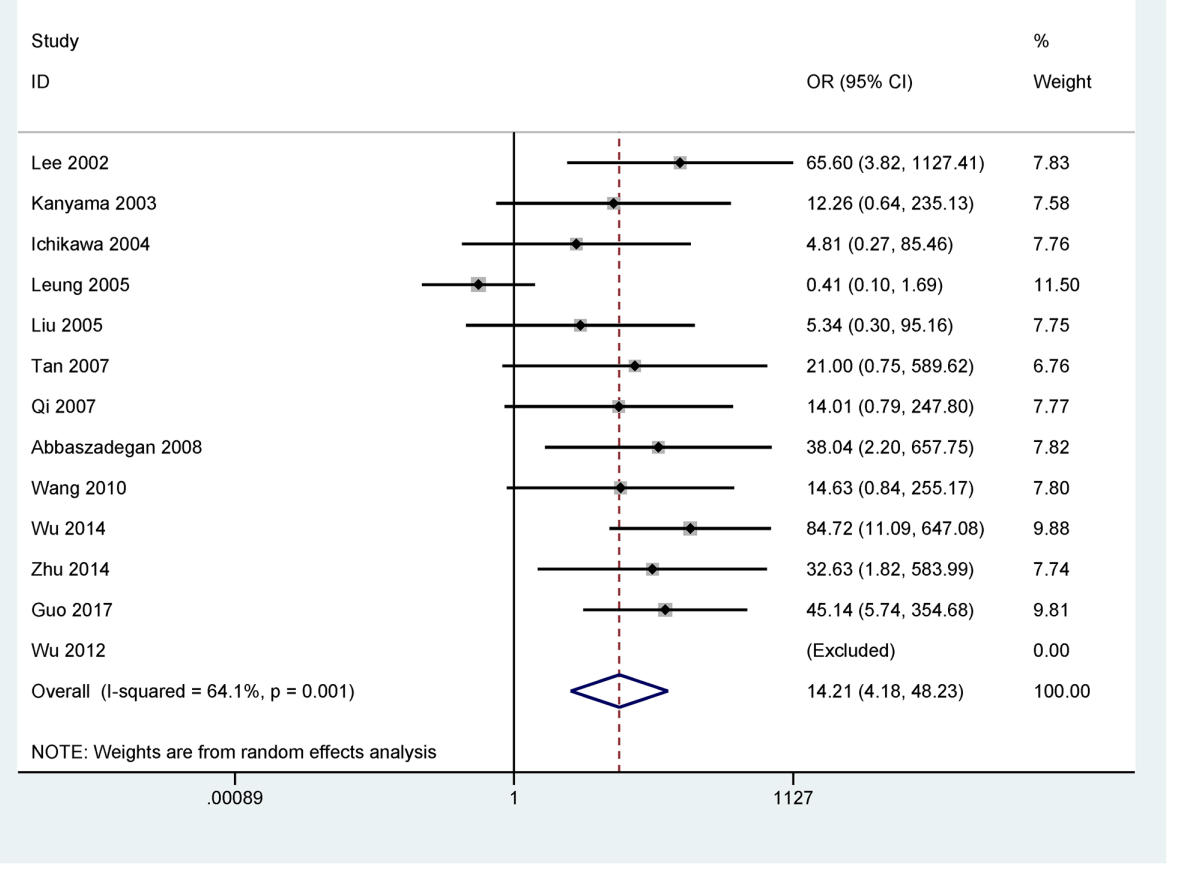

Figure 2: Forest plot of the association between p16 promotermethylation and GC in blood samples (877 GC patients and 307 non-tumor controls), $\mathrm{OR}=\mathbf{1 4 . 2 1}, \mathbf{9 5} \% \mathrm{CI}=\mathbf{4 . 1 8 - 4 8 . 2 3}, P<\mathbf{0 . 0 0 1}$, methylation frequency (cancer vs control group): $31.0 \%$ vs $2.0 \%$.

\begin{tabular}{|c|c|c|}
\hline \multicolumn{2}{|l|}{ Study } & \multirow{2}{*}{$\%$} \\
\hline ID & OR $(95 \% \mathrm{Cl})$ & \\
\hline \multicolumn{3}{|l|}{$\mathrm{CDH} 1$} \\
\hline Lee 2002 & $81.77(4.75,1406.57)$ & 5.86 \\
\hline Ichikawa 2004 & $6.66(0.38,117.60)$ & 5.80 \\
\hline Leung 2005 & $7.29(0.40,131.70)$ & 5.74 \\
\hline Tan 2007 & $9.00(0.29,275.56)$ & 4.60 \\
\hline Qi 2007 & $25.86(1.48,451.29)$ & 5.83 \\
\hline Bernal 2008 & $16.67(3.53,78.81)$ & 10.28 \\
\hline Liu 2012 & $29.92(1.76,509.27)$ & 5.89 \\
\hline Zhu 2014 & $24.66(1.36,445.60)$ & 5.74 \\
\hline Wu 2012 & (Excluded) & 0.00 \\
\hline Subtotal $(I-$ squared $=0.0 \%, p=0.935)$ & $18.19(7.38,44.80)$ & 49.73 \\
\hline \multicolumn{3}{|l|}{ RUNX3 } \\
\hline Tan 2007 & $189.00(3.22,11095.09)$ & 3.57 \\
\hline Sakakura 2009 & $33.72(9.27,122.71)$ & 11.40 \\
\hline Zheng 2011 & $15.65(3.47,70.64)$ & 10.47 \\
\hline Lu 2012 & $933.14(225.45,3862.25)$ & 10.84 \\
\hline Liu 2012 & $48.60(2.88,821.30)$ & 5.91 \\
\hline Zhu 2014 & $19.84(2.39,164.42)$ & 8.07 \\
\hline Subtotal $(\mathrm{I}$-squared $=75.0 \%, p=0.001)$ & $63.66(13.42,302.02)$ & 50.27 \\
\hline Overall & & 100.00 \\
\hline NOTE: Weights are from random effects analysi\$ & & \\
\hline $9.0 \mathrm{e}-05$ & 11095 & \\
\hline
\end{tabular}

Figure 3: Forest plot of the association between $C D H 1$ (569 GC patients and 223 non-tumor controls) and $R U N X 3$ (440 GC patients and 942 non-tumor controls) promoter methylation and GC in blood samples, $C D H 1: O R=18.19,95 \% \mathrm{CI}$ $=7.38-44.80, P<0.001$, methylation frequency (cancer vs control group): $24.3 \%$ vs $0.9 \% ; R U N X 3:$ OR $=63.66,95 \% \mathrm{CI}=13.42-$ 302.02, $P<\mathbf{0 . 0 0 1}$, methylation frequency (cancer vs control group): $63.2 \%$ vs $2.5 \%$. 
MLH1, RASSF1A, p15, APC, DAPK, GSTP1, Reprimo, and $M G M T$ ) promoter methylation test using blood samples as a feasible biomarker in GC diagnosis and screening.

Some studies reported that promoter methylation of the p16,CDH1, RUNX3, MLH1, RASSF1A, p15, APC, $D A P K$, GSTP1, Reprimo, and MGMT was frequent in the blood in patients with GC [34-38]. However, the results of the frequencies of promoter methylation of these 11 tumor-related genes are conflicting and different in blood samples of GC patients and non-tumor controls. For example, Wu 2012 et al reported that no promoter methylation of the $p 16$ gene was detected in GC and non- tumor controls [39]. While Leung 2005 et al reported that $p 16$ promoter methylation in GC was significantly lower than in controls (8.3\% vs $18.2 \%$ ) [29]. Promoter methylation of the P16 gene had a higher level in GC than in controls among numerous studies [38, 40-43]. CDH1 promoter methylation showed a frequency from $0 \%$ [39] to $57.4 \%$ [38] in blood samples of patients with GC, and a frequency from $0 \%$ [39] to $6.5 \%$ [22] in normal controls. Tan 2007 et al reported that $R U N X 3$ promoter methylation was found in all four GC patients and was not detected in 10 controls [44]. Some studies demonstrated that the frequency of $R U N X 3$ promoter methylation ranged from $37.3 \%$ [45] to $95.4 \%$ [36] in blood samples of GC patients.

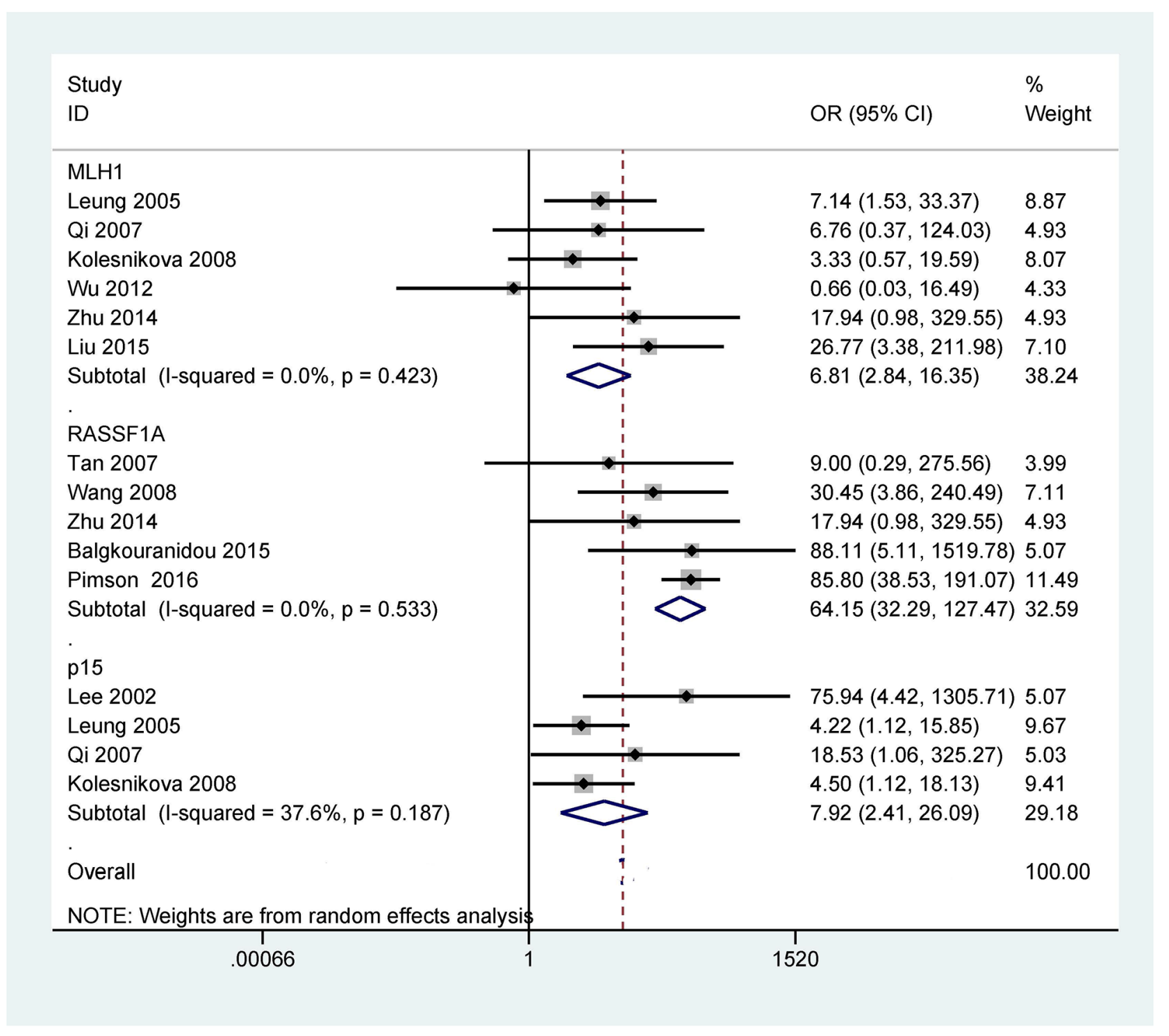

Figure 4: Forest plot of the association between $M L H 1$ (354 GC patients and 154 non-tumor controls), $R A S S F 1 A$ (257 GC patients and 322 non-tumor controls), and p15 (186 GC patients and 94 non-tumor controls) promoter methylation and GC in blood samples, $M L H 1: \mathrm{OR}=\mathbf{6 . 8 1 , 9 5 \%} \mathrm{CI}=\mathbf{2 . 8 4}-\mathbf{1 6 . 3 5}, \boldsymbol{P}<\mathbf{0 . 0 0 1}$, methylation frequency (cancer vs control group): $19.5 \%$ vs $3.2 \%$; RASSF1A: $\mathrm{OR}=64.15,95 \% \mathrm{CI}=32.29-127.47, P<0.001$, methylation frequency (cancer vs control group): $61.5 \%$ vs $3.7 \%$; and $p 15$ : $\mathrm{OR}=\mathbf{7 . 9 2 , 9 5 \%} \mathrm{CI}=\mathbf{2 . 4 1 - 2 6 . 0 9}, P=\mathbf{0 . 0 0 1}$, methylation frequency (cancer vs control group): $43.0 \%$ vs $7.4 \%$. 
Moreover, only Sakakura 2009 et al recorded that $R U N X 3$ promoter methylation had a frequency of $>5 \%$ in nontumor controls [36].

The frequency of $M L H 1$ promoter methylation was not very high in blood samples of patients with GC, with a range from $0.7 \%$ [39] to $48 \%$ [46]. RASSF $1 A$ gene within the promoter had a low methylation rate (34\%) in the blood in GC by Wang 2008 et al [47], on the other hand, Pimson 2016 et al reported that RASSF $1 A$ gene within the promoter had a high methylation level $(83.2 \%)$ in blood samples of GC [48]. p15 gene within the promoter was methylated with a frequency of $<60 \%$ in blood samples of patients with GC [29, 37, 38]. APC promoter methylation had a similar and high level in the blood of GC and controls (76.7\% vs 64.5\%) [22]. While $A P C$ promoter methylation showed a low level in blood samples of GC and controls (16.7\% vs $0 \%$ ) by Leung 2005 et al [29]. $D A P K$ gene within the promoter was found to

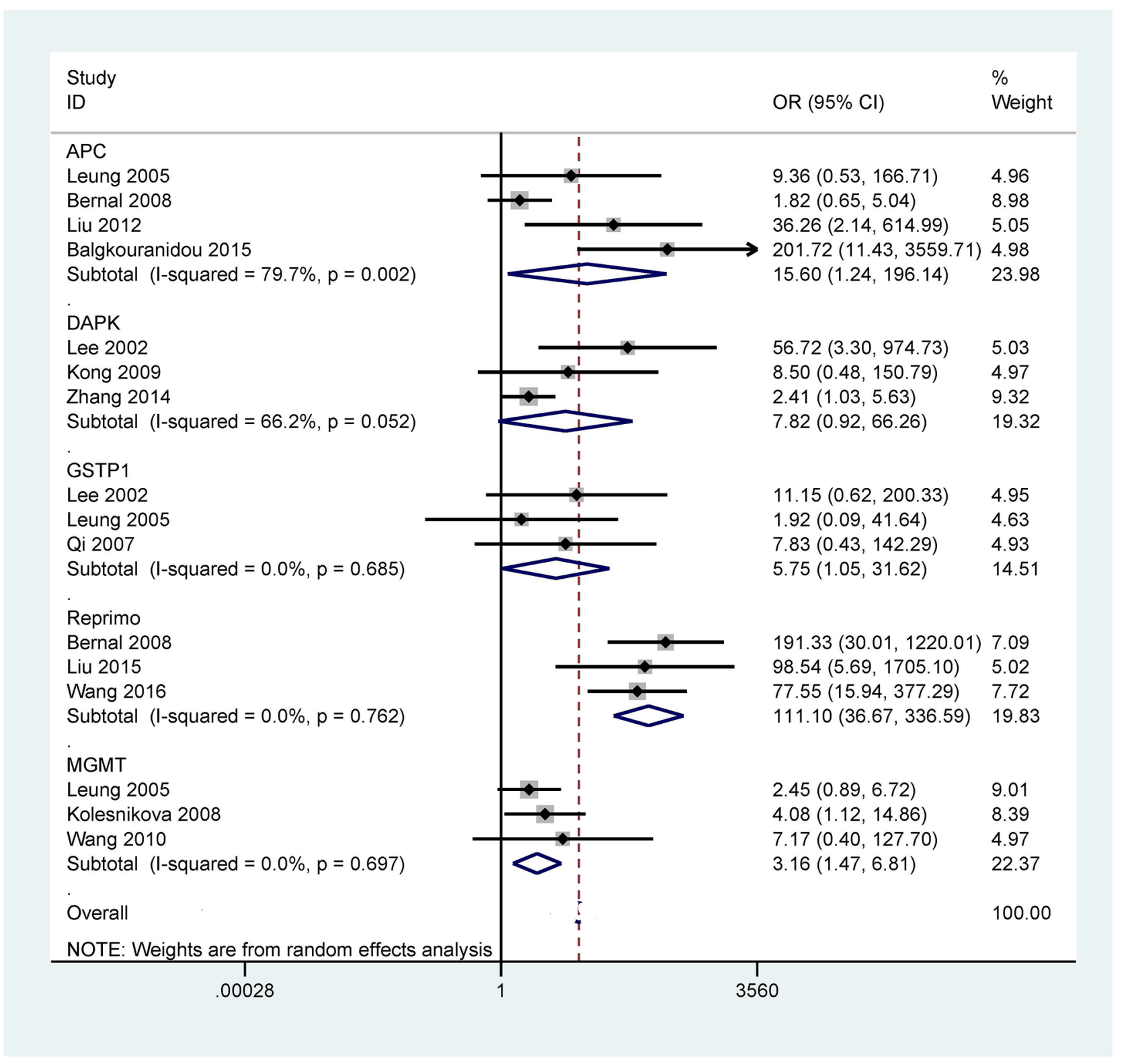

Figure 5: Forest plot of the correlation between $A P C(\mathrm{OR}=15.60,95 \% \mathrm{CI}=1.24-196.14, P=0.033$, methylation frequency (cancer vs control group): $50.6 \%$ vs $17.7 \%), D A P K(\mathrm{OR}=7.82,95 \% \mathrm{CI}=0.92-66.26, P=0.059)$, GSTP1 $(\mathrm{OR}=5.75,95 \% \mathrm{CI}=1.05$ $31.62, P=0.044$, methylation frequency (cancer vs control group): $10.8 \%$ vs $0.0 \%)$, $\operatorname{Reprimo}(\mathrm{OR}=111.10,95 \% \mathrm{CI}=36.67-336.59, P$ $<0.001$, methylation frequency (cancer vs control group): $82.0 \%$ vs $11.0 \%)$, and $M G M T(\mathrm{OR}=3.16,95 \% \mathrm{CI}=1.47-6.81, P=0.003$, methylation frequency (cancer vs control group): $40.9 \%$ vs $26.7 \%$ ) promoter methylation and GC in the blood. 
be methylated among both GC and controls (49.1\% vs $28.6 \%$ ) [49]. While only promoter methylation of the $D A P K$ gene was reported in GC by Lee 2002 et al [38]. GSTP1 promoter methylation had a frequency of $<20 \%$ in blood samples of GC patients [29, 38]. Reprimo promoter methylation had a high rate in blood samples of patients with GC (>60\%) [22, 34, 46]. Leung 2005 et al showed no correlation between $M G M T$ promoter methylation and GC [29]. A significant correlation was reported between $M G M T$ promoter methylation and GC by Kolesnikova 2008 et al [37].

The current analyses comprising all eligible articles revealed that promoter methylation of the $p 16, C D H 1$, RUNX3, MLH1, RASSF1A, p15, APC, GSTP1, Reprimo, and $M G M T$ was significantly higher in blood samples of patients with GC compared with non-tumor controls. But $D A P K$ promoter methylation had a similar frequency in the blood in GC and controls, these results suggested that promoter methylation of the ten tumor-related genes ( $p 16$, CDH1, RUNX3, MLH1, RASSF1A, p15, APC, GSTP1, Reprimo, and $M G M T$ ) may be potential biomarkers based-blood test for GC. In our study, we found different methylation frequencies of the ten tumor-related genes in blood samples in GC vs controls ( $p 16: 31.0 \%$ vs $2.0 \%$, CDH1: $24.3 \%$ vs $0.9 \%$, RUNX3: $63.2 \%$ vs $2.5 \%, M L H 1$ : $19.5 \%$ vs $3.2 \%$, RASSF $1 A: 61.5 \%$ vs $3.7 \%$, p15: $43.0 \%$ vs $7.4 \%, A P C: 50.6 \%$ vs $17.7 \%$, GSTP $1: 10.8 \%$ vs $0.0 \%$,
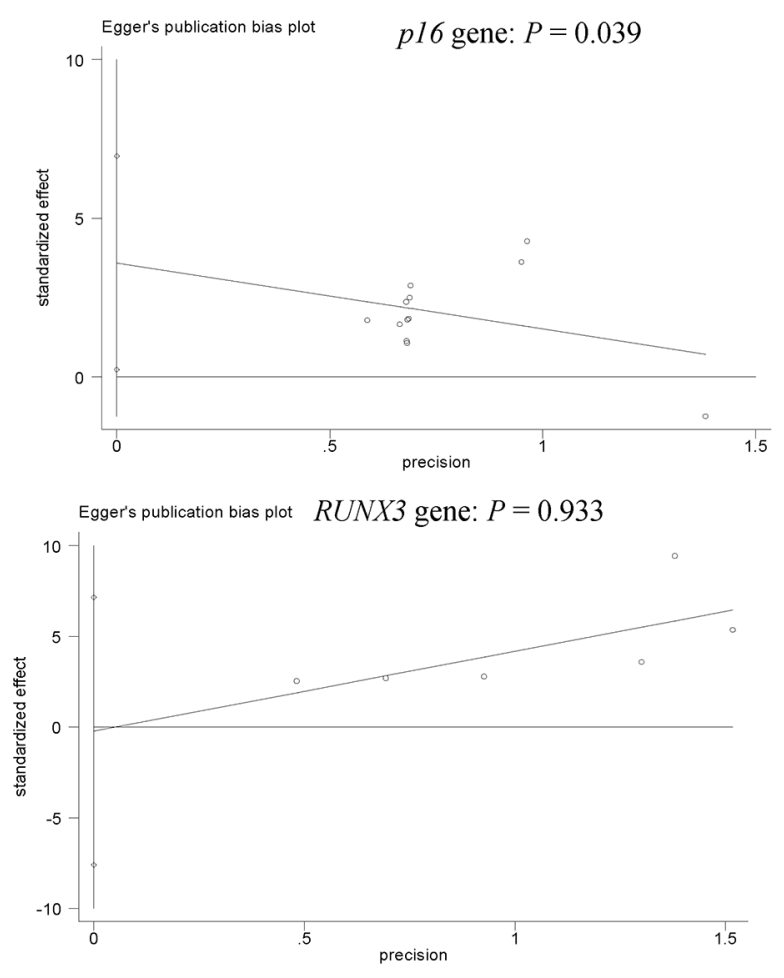

Reprimo: $82.0 \%$ vs $11.0 \%$, and $M G M T$ : $40.9 \%$ vs $26.7 \%$ ) (Supplementary Table 2).

Numerous studies suggested that promoter methylationof the RUNX3, RASSF $1 A$ and Reprimo genes was more common in GC tissues compared with normal tissues, suggesting that promoter methylation of the RUNX3, RASSF 1A, and Reprimo genes may induce the tumorigenesis of gastric cancer [50-53]. Additionally, RASSF $1 A$ promoter methylation had a frequency of $93 \%$ in blood samples of colorectal cancer and a frequency of $61.6 \%$ in non-cancer controls [54], but had a low frequency in lung cancer (37.1\%) [55] and nasopharyngeal carcinoma (19\%) in the blood [5]. RUNX3 promoter methylation was shown to have a frequency of $43.9 \%$ in blood samples of lung cancer [55]. Nishio et al reported that $R U N X 3$ promoter methylation showed a frequency of $29 \%$ in the blood of a large colorectal cancer patients (344 cases) [56]. Reprimo methylation was not frequently studied in blood samples of other human cancers. Ellinger et al reported that Reprimo promoter methylation had a very low frequency $(1.2 \%)$ in blood samples of prostate cancer [57]. The current analyses indicated that the three RUNX3, RASSF1A and Reprimo genes promoter methylation had better diagnostic capacity (RUNX3: sensitivity $=63.2 \%$ and specificity $=97.5 \%, R A S S F 1 A$ : sensitivity $=61.5 \%$ and specificity $=96.3 \%$, Reprimo: sensitivity $=82.0 \%$ and specificity $=89.0 \%$, which
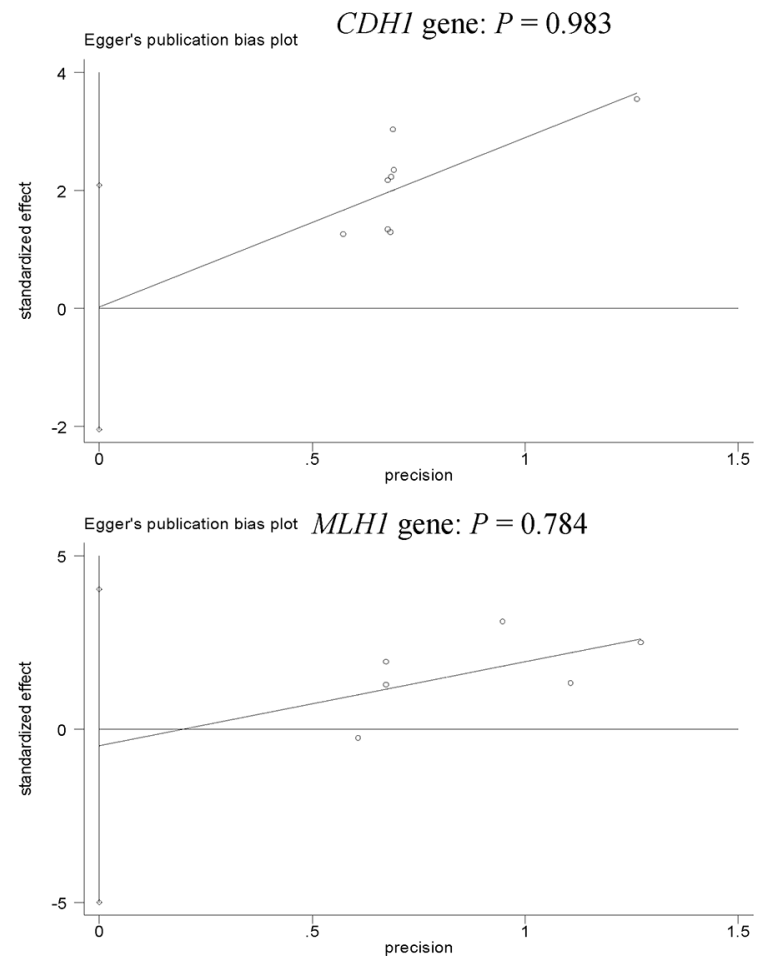

Figure 6: Forest plot of publication bias using Egger's test in the $p 16$ (cancer vs control group: $P=0.039<0.05$ ), $C D H 1$, $R U N X 3$, and $M L H 1$ genes (cancer vs control group: all $P s>0.05$ ). 
suggested that the three tumor-related genes could become potential noninvasive biomarkers using blood samples for the early detection of GC, particularly Reprimo promoter methylation.

When GC was compared to non-tumor controls in the blood, significant heterogeneity was detected in the p16, RUNX3, and $A P C$ genes $(P<0.1)$. When we removed one study (Leung 2005 et al) [29] in p16 promoter methylation, this study by Lu 2012 et al [30] in RUNX3 promoter methylation, and one study by Bernal 2008 et al [22] in APC promoter methylation. The re-calculated OR remained significant in the sensitivity analyses, with no obvious evidence of heterogeneity $(P>0.1)$. The reasons for the observed bias were not very clear, perhaps due to the use of inappropriate or different conditions in methylation detection.

Several limitations of the present study should be considered. First, our study mainly included Asian population, and partly consisted of Caucasian population. While Africans were lacking. Second, a slight evidence of publication bias was measured in the p16 gene, only eligible articles published in English or Chinese were included in our analysis. Other papers in other languages and unpublished studies and conference abstracts, were excluded because of the insufficient information, which may result in a slight bias. Third, the sample sizes and studies of gene promoter methylation with clinicopathological features were small. More welldesigned studies with large sample sizes, detained clinical stages and prognostic analysis are needed in blood samples of GC in the future. Finally, gene methylation with fewer than three studies should be further done in large populations.

In conclusion, the current findings reveal that $p 16$, CDH1, RUNX3, MLH1, RASSF1A, p15, APC, GSTP1, Reprimo, or $M G M T$ promoter methylation is associated with blood samples of patients with GC. RUNX3, RASSF1A and Reprimo promoter methylation may be potential useful noninvasive biomarkers for the detection of $\mathrm{GC}$, but other p16, CDH1, MLH1, p15, APC, GSTP1, and MGMT genes show a low diagnostic effect for GC in blood samples. Additional clinical prospective researches with larger populations of blood samples are essential to further validate the diagnostic and screening value of the RUNX3, RASSF $1 A$ and Reprimo promoter methylation in GC.

\section{MATERIALS AND METHODS}

\section{Search strategy}

PubMed, EMBASE, EBSCO, Wanfang, and CNKI databases were searched to find eligible publications prior to April 28, 2017. We used the following key words and free terms: (stomach OR gastric) AND (cancer OR tumor OR neoplasm OR carcinoma) AND (blood OR serum OR sera OR plasma) AND (methylation OR methylated OR hypermethylation OR epigenetic silencing OR epigenetic inactivation). A manual search from the reference lists of the included studies was performed for other potential articles.

\section{Study selection}

The eligible studies were selected if they satisfied the inclusion criteria: 1) the patients were limited to the diagnosis of GC; 2) case-control or cohort studies reported the information between gene promoter methylation and GC in blood samples; 3) studies provided sufficient data to assess the difference of gene promoter methylation between GC and controls without cancer, and the correlation of gene promoter methylation with clinicopathological features of GC. Only the article with the most detailed information was chosen when the overlapping study populations were reported in several papers published.

\section{Data extraction}

The following data were extracted using a standardized form: first author's surname, year of publication, study location, ethnicity, mean or median age, methylation detect methods, cancer stage, sample size of cases and controls, control types, and GC patients' characteristics, such as gender (male vs female), age ( $\geq 60$ years vs $<60$ years), clinical stage (stage $3-4$ vs stage $1-2$ ) and lymph node status (positive vs negative).

\section{Data analysis}

The pooled data were analyzed using Stata software (version 12.0, Stata Corporation, College Station, TX, USA). The overall odds ratios (ORs) with the corresponding $95 \%$ confidence intervals (95\% CIs) were calculated to evaluate the relationship of gene promoter methylation between GC and controls in blood samples. Moreover, the correlation of gene promoter methylation with clinicopathological characteristics of GC was performed among more than one study. The Cochran's Q statistic was used to estimate the possible heterogeneity among the included studies [58]. The random-effects model was chosen to make the results more reliable in the meta-analysis. When there was substantial heterogeneity $(P<0.1)$ for the results with more than two studies, we conducted a sensitivity analysis of the omission of an individual study to assess the change of the recalculated OR and heterogeneity [59, 60]. The possible publication bias was estimated using Egger's test for methylated genes with more than five studies [61].

\section{Author contributions}

Jinfeng Wen and Guoliang Ye conceived and designed the study. Jinfeng Wen, Tuo Zheng, Kefeng Hu, 
Chunxia Zhu, Lihua Guo, and Guoliang Ye contributed to the retrieval of articles, the extraction of data, the calculation of data and the design of the figures and tables. All authors approved the final manuscript.

\section{ACKNOWLEDGMENTS}

This research was supported by grants from the Ningbo Natural Science Foundation (2016C51015).

\section{CONFLICTS OF INTEREST}

The authors declare that they have no competing financial interests.

\section{REFERENCES}

1. Torre LA, Bray F, Siegel RL, Ferlay J, Lortet-Tieulent J, Jemal A. Global cancer statistics, 2012. CA Cancer J Clin. 2015; 65:87-108.

2. Ferlay J, Soerjomataram I, Dikshit R, Eser S, Mathers C, Rebelo M, Parkin DM, Forman D, Bray F. Cancer incidence and mortality worldwide: sources, methods and major patterns in GLOBOCAN 2012. Int J Cancer. 2015; 136:E359-E386.

3. GASTRIC (Global Advanced/Adjuvant Stomach Tumor Research International Collaboration) Group, Oba K, Paoletti X, Bang YJ, Bleiberg H, Burzykowski T, Fuse N, Michiels S, Morita S, Ohashi Y, Pignon JP, Rougier P, Sakamoto J, et al. Role of chemotherapy for advanced/ recurrent gastric cancer: an individual-patient-data metaanalysis. Eur J Cancer. 2013; 49:1565-1577.

4. Hartgrink HH, Jansen EP, van Grieken NC, van de Velde CJ. Gastric cancer. Lancet. 2009; 374:477-490.

5. Ye M, Huang T, Ni C, Yang P, Chen S. Diagnostic capacity of RASSF1A promoter methylation as a biomarker in tissue, brushing, and blood samples of nasopharyngeal carcinoma. EBioMedicine. 2017; 18:32-40.

6. Pisanic TR 2nd, Athamanolap P, Wang TH. Defining, distinguishing and detecting the contribution of heterogeneous methylation to cancer heterogeneity. Semin Cell Dev Biol. 2017; 64:5-17.

7. Zhao R, Choi BY, Lee MH, Bode AM, Dong Z. Implications of genetic and epigenetic alterations of CDKN2A (p16(INK4a)) in cancer. EBioMedicine. 2016; 8:30-39.

8. Wielscher M, Vierlinger K, Kegler U, Ziesche R, Gsur A, Weinhausel A. Diagnostic performance of plasma DNA methylation profiles in lung cancer, pulmonary fibrosis and COPD. EBioMedicine. 2015; 2:929-936.

9. Nagata S, Hamada T, Yamada N, Yokoyama S, Kitamoto S, Kanmura Y, Nomura M, Kamikawa Y, Yonezawa S, Sugihara K. Aberrant DNA methylation of tumorrelated genes in oral rinse: a noninvasive method for detection of oral squamous cell carcinoma. Cancer. 2012; 118:4298-4308.

10. Renard I, Joniau S, van Cleynenbreugel B, Collette C, Naome C, Vlassenbroeck I, Nicolas H, de Leval J, Straub J, Van Criekinge W, Hamida W, Hellel M, Thomas A, et al. Identification and validation of the methylated TWIST1 and NID2 genes through real-time methylation-specific polymerase chain reaction assays for the noninvasive detection of primary bladder cancer in urine samples. Eur Urol. 2010; 58:96-104.

11. Ni S, Ye M, Huang T. Short stature homeobox 2 methylation as a potential noninvasive biomarker in bronchial aspirates for lung cancer diagnosis. Oncotarget. 2017; 8:6125361263. https://doi.org/10.18632/oncotarget.18056.

12. Furonaka O, Takeshima Y, Awaya H, Ishida H, Kohno N, Inai K. Aberrant methylation of p14(ARF), p15(INK4b) and p16(INK4a) genes and location of the primary site in pulmonary squamous cell carcinoma. Pathol Int. 2004; 54:549-555.

13. Canel M, Serrels A, Frame MC, Brunton VG. E-cadherinintegrin crosstalk in cancer invasion and metastasis. J Cell Sci. 2013; 126:393-401.

14. Li L, Hartley R, Reiss B, Sun Y, Pu J, Wu D, Lin F, Hoang T, Yamada S, Jiang J, Zhao M. E-cadherin plays an essential role in collective directional migration of large epithelial sheets. Cell Mol Life Sci. 2012; 69:2779-2789.

15. Li QL, Ito K, Sakakura C, Fukamachi H, Inoue K, Chi XZ, Lee KY, Nomura S, Lee CW, Han SB, Kim HM, Kim WJ, Yamamoto H, et al. Causal relationship between the loss of RUNX3 expression and gastric cancer. Cell. 2002; 109:113-124.

16. Ottini L, Falchetti M, Lupi R, Rizzolo P, Agnese V, Colucci G, Bazan V, Russo A. Patterns of genomic instability in gastric cancer: clinical implications and perspectives. Ann Oncol. 2006; 17:vii97-102.

17. Leung SY, Yuen ST, Chung LP, Chu KM, Chan AS, Ho JC. hMLH1 promoter methylation and lack of hMLH1 expression in sporadic gastric carcinomas with highfrequency microsatellite instability. Cancer Res. 1999; 59:159-164.

18. Agathanggelou A, Cooper WN, Latif F. Role of the Rasassociation domain family 1 tumor suppressor gene in human cancers. Cancer Res. 2005; 65:3497-3508.

19. Shen C, Sheng Q, Zhang X, Fu Y, Zhu K. Hypermethylated APC in serous carcinoma based on a meta-analysis of ovarian cancer. J Ovarian Res. 2016; 9:60.

20. Masood N, Kayani MA. Expression patterns of carcinogen detoxifying genes (CYP1A1, GSTP1 \& GSTT1) in HNC patients. Pathol Oncol Res. 2013; 19:89-94.

21. Hayes JD, Flanagan JU, Jowsey IR. Glutathione transferases. Annu Rev Pharmacol Toxicol. 2005; 45:51-88.

22. Bernal C, Aguayo F, Villarroel C, Vargas M, Diaz I, Ossandon FJ, Santibanez E, Palma M, Aravena E, 
Barrientos C, Corvalan AH. Reprimo as a potential biomarker for early detection in gastric cancer. Clin Cancer Res. 2008; 14:6264-6269.

23. Huang Y, Chen L, Guo L, Hupp TR, Lin Y. Evaluating DAPK as a therapeutic target. Apoptosis. 2014; 19:371-386.

24. Shibata T, Glynn N, McMurry TB, McElhinney RS, Margison GP, Williams DM. Novel synthesis of O6-alkylguanine containing oligodeoxyribonucleotides as substrates for the human DNA repair protein, O6-methylguanine DNA methyltransferase (MGMT). Nucleic Acids Res. 2006; 34:1884-1891.

25. Esteller M, Garcia-Foncillas J, Andion E, Goodman SN, Hidalgo OF, Vanaclocha V, Baylin SB, Herman JG. Inactivation of the DNA-repair gene MGMT and the clinical response of gliomas to alkylating agents. N Engl J Med. 2000; 343:1350-1354.

26. Kupcinskaite-Noreikiene R, Ugenskiene R, Noreika A, Rudzianskas V, Gedminaite J, Skieceviciene J, Juozaityte E. Gene methylation profile of gastric cancerous tissue according to tumor site in the stomach. BMC Cancer. 2016; 16:40.

27. Zou XP, Zhang B, Zhang XQ, Chen M, Cao J, Liu WJ. Promoter hypermethylation of multiple genes in early gastric adenocarcinoma and precancerous lesions. Hum Pathol. 2009; 40:1534-1542.

28. Tamura G. Promoter methylation status of tumor suppressor and tumor-related genes in neoplastic and non-neoplastic gastric epithelia. Histol Histopathol. 2004; 19:221-228

29. Leung WK, To KF, Chu ES, Chan MW, Bai AH, Ng EK, Chan FK, Sung JJ. Potential diagnostic and prognostic values of detecting promoter hypermethylation in the serum of patients with gastric cancer. Br J Cancer. 2005; 92:2190-2194.

30. Lu XX, Yu JL, Ying LS, Han J, Wang S, Yu QM, Wang XB, Fang XH, Ling ZQ. Stepwise cumulation of RUNX3 methylation mediated by Helicobacter pylori infection contributes to gastric carcinoma progression. Cancer. 2012; 118:5507-5517.

31. Ye M, Huang T, Ying Y, Li J, Yang P, Ni C, Zhou C, Chen S. Detection of 14-3-3 sigma $(\sigma)$ promoter methylation as a noninvasive biomarker using blood samples for breast cancer diagnosis. Oncotarget. 2017; 8:9230-9242. https:// doi.org/10.18632/oncotarget.13992.

32. Potter NT, Hurban P, White MN, Whitlock KD, Lofton-Day CE, Tetzner R, Koenig T, Quigley NB, Weiss G. Validation of a real-time PCR-based qualitative assay for the detection of methylated SEPT9 DNA in human plasma. Clin Chem. 2014; 60:1183-1191.

33. Hoque MO, Begum S, Topaloglu O, Jeronimo C, Mambo E, Westra WH, Califano JA, Sidransky D. Quantitative detection of promoter hypermethylation of multiple genes in the tumor, urine, and serum DNA of patients with renal cancer. Cancer Res. 2004; 64:5511-5517.
34. Wang H, Zheng $\mathrm{Y}$, Lai J, Luo Q, Ke H, Chen Q. Methylation-sensitive melt curve analysis of the reprimo gene methylation in gastric cancer. PLoS One. 2016; 11:e0168635.

35. Balgkouranidou I, Matthaios D, Karayiannakis A, Bolanaki $\mathrm{H}$, Michailidis P, Xenidis N, Amarantidis K, Chelis L, Trypsianis G, Chatzaki E, Lianidou ES, Kakolyris S. Prognostic role of APC and RASSF1A promoter methylation status in cell free circulating DNA of operable gastric cancer patients. Mutat Res. 2015; 778:46-51.

36. Sakakura C, Hamada T, Miyagawa K, Nishio M, Miyashita A, Nagata H, Ida H, Yazumi S, Otsuji E, Chiba T, Ito K, Ito Y. Quantitative analysis of tumor-derived methylated RUNX3 sequences in the serum of gastric cancer patients. Anticancer Res. 2009; 29:2619-2625.

37. Kolesnikova EV, Tamkovich SN, Bryzgunova OE, Shelestyuk PI, Permyakova VI, Vlassov VV, Tuzikov AS, Laktionov PP, Rykova EY. Circulating DNA in the blood of gastric cancer patients. Ann N Y Acad Sci. 2008; 1137:226-231.

38. Lee TL, Leung WK, Chan MW, Ng EK, Tong JH, Lo KW, Chung SC, Sung JJ, To KF. Detection of gene promoter hypermethylation in the tumor and serum of patients with gastric carcinoma. Clin Cancer Res. 2002; 8:1761-1766.

39. Wu PY, Zhang Z, Wang JM, Guo WW, Xiao N, He Q, Wang YP, Fan YM. Germline promoter hypermethylation of tumor suppressor genes in gastric cancer. World J Gastroenterol. 2012; 18:70-78.

40. Guo L, Huang C, Ji QJ. Aberrant promoter hypermethylation of $\mathrm{p} 16$, survivin, and retinoblastoma in gastric cancer. Bratisl Lek Listy. 2017; 118:164-168.

41. Wu YC, Lv P, Han J, Yu JL, Zhu X, Hong LL, Zhu WY, Yu QM, Wang XB, Li P, Ling ZQ. Enhanced serum methylated p16 DNAs is associated with the progression of gastric cancer. Int J Clin Exp Pathol. 2014; 7:1553-1562.

42. Abbaszadegan MR, Moaven O, Sima HR, Ghafarzadegan K, A'Rabi A, Forghani MN, Raziee HR, Mashhadinejad A, Jafarzadeh M, Esmaili-Shandiz E, Dadkhah E. p16 promoter hypermethylation: a useful serum marker for early detection of gastric cancer. World J Gastroenterol. 2008; 14:2055-2060.

43. Kanyama Y, Hibi K, Nakayama H, Kodera Y, Ito K, Akiyama S, Nakao A. Detection of p16 promoter hypermethylation in serum of gastric cancer patients. Cancer Sci. 2003; 94:418-420.

44. Tan SH, Ida H, Lau QC, Goh BC, Chieng WS, Loh M, Ito Y. Detection of promoter hypermethylation in serum samples of cancer patients by methylation-specific polymerase chain reaction for tumour suppressor genes including RUNX3. Oncol Rep. 2007; 18:1225-1230.

45. Liu JB, Wu XM, Cai J, Zhang JY, Zhang JL, Zhou SH, Shi MX, Qiang FL. CpG island methylator phenotype and Helicobacter pylori infection associated with gastric cancer. World J Gastroenterol. 2012; 18:5129-5134. 
46. Liu L, Yang X. Implication of Reprimo and hMLH1 gene methylation in early diagnosis of gastric carcinoma. Int $\mathrm{J}$ Clin Exp Pathol. 2015; 8:14977-14982.

47. Wang YC, Yu ZH, Liu C, Xu LZ, Yu W, Lu J, Zhu RM, Li GL, Xia XY, Wei XW, Ji HZ, Lu H, Gao Y, et al. Detection of RASSF1A promoter hypermethylation in serum from gastric and colorectal adenocarcinoma patients. World J Gastroenterol. 2008; 14:3074-3080.

48. Pimson C, Ekalaksananan T, Pientong C, Promthet S, Putthanachote N, Suwanrungruang $\mathrm{K}$, Wiangnon $\mathrm{S}$. Aberrant methylation of PCDH10 and RASSF1A genes in blood samples for non-invasive diagnosis and prognostic assessment of gastric cancer. PeerJ. 2016; 4:e2112.

49. Zhang X, Zhang X, Sun B, Lu H, Wang D, Yuan X, Huang Z. Detection of aberrant promoter methylation of RNF180, DAPK1 and SFRP2 in plasma DNA of patients with gastric cancer. Oncol Lett. 2014; 8:1745-1750.

50. Fan XY, Hu XL, Han TM, Wang NN, Zhu YM, Hu W, Ma ZH, Zhang CJ, Xu X, Ye ZY, Han CM, Pan WS. Association between RUNX3 promoter methylation and gastric cancer: a meta-analysis. BMC Gastroenterol. 2011; 11:92.

51. Liu X, Wang L, Guo Y. The association between runtrelated transcription factor 3 gene promoter methylation and gastric cancer: a meta-analysis. J Cancer Res Ther. 2016; 12:50-53.

52. Ooki A, Yamashita K, Yamaguchi K, Mondal A, Nishimiya $\mathrm{H}$, Watanabe M. DNA damage-inducible gene, reprimo functions as a tumor suppressor and is suppressed by promoter methylation in gastric cancer. Mol Cancer Res. 2013; 11:1362-1374.

53. Shi DT, Han M, Gao N, Tian W, Chen W. Association of RASSF1A promoter methylation with gastric cancer risk: a meta-analysis. Tumour Biol. 2014; 35:943-948.
54. Cassinotti E, Melson J, Liggett T, Melnikov A, Yi Q, Replogle C, Mobarhan S, Boni L, Segato S, Levenson V. DNA methylation patterns in blood of patients with colorectal cancer and adenomatous colorectal polyps. Int J Cancer. 2012; 131:1153-1157.

55. Wang BH, Li YY, Han JZ, Zhou LY, Lv YQ, Zhang HL, Zhao L. Gene methylation as a powerful biomarker for detection and screening of non-small cell lung cancer in blood. Oncotarget. 2017; 8:31692-31704. https://doi. org/10.18632/oncotarget.15919.

56. Nishio M, Sakakura C, Nagata T, Komiyama S, Miyashita A, Hamada T, Kuryu Y, Ikoma H, Kubota T, Kimura A, Nakanishi M, Ichikawa D, Fujiwara H, et al. RUNX3 promoter methylation in colorectal cancer: its relationship with microsatellite instability and its suitability as a novel serum tumor marker. Anticancer Res. 2010; 30:2673-2682.

57. Ellinger J, Haan K, Heukamp LC, Kahl P, Buttner R, Muller SC, von Ruecker A, Bastian PJ. CpG island hypermethylation in cell-free serum DNA identifies patients with localized prostate cancer. Prostate. 2008; 68:42-49.

58. Coory MD. Comment on: Heterogeneity in meta-analysis should be expected and appropriately quantified. Int $\mathrm{J}$ Epidemiol. 2010; 39:932; author reply 933.

59. Higgins JP, Thompson SG, Deeks JJ, Altman DG. Measuring inconsistency in meta-analyses. BMJ. 2003; 327:557-560.

60. Lau J, Ioannidis JP, Schmid CH. Quantitative synthesis in systematic reviews. Ann Intern Med. 1997; 127:820-826.

61. Egger M, Davey Smith G, Schneider M, Minder C. Bias in meta-analysis detected by a simple, graphical test. BMJ. 1997; 315:629-634. 